\title{
THE USE OF MODERN TECHNOLOGIES IN THE LIFE AND WORK OF TEACHERS BEFORE AND DURING COVID VIRUS ${ }^{* *}$
}

\begin{abstract}
Modern technologies are present in almost every part of human`s life and work. One of the most important spheres of human's life is an education. The penetration of modern technologies in this life`s sphere is huge, especially in last several years. These facts purport that teachers, professors and other educators must introduce and teach their pupils to use these technologies on appropriate way. This role is very important and complex. Teachers must find appropriate way to realize balance between "digital" skills needed for pupils to accept the school material, use benefits of "digital" environment and continue to use and develop the imagination and other activities used by older "no digital" generations. So, teachers must continuously learn and become acquainted with modern technologies and their benefits and use them in life and work. The modern technologies are different, but in elementary schools, secondary schools and houses of students, the most frequently used are mobile phones, laptops, tablets, Internet, social networks etc. The main goal of this paper is to present the results of use of noted modern technologies in life and work of teachers. Researches presented in this paper were realized by author of this paper as longitudinal researches and included teachers in different educational institutions, such as elementary schools, secondary schools in Niš and in pupil's homes.
\end{abstract}

Keywords: modern technologies, school, teachers, Covid.

*milan.jvtc@gmail.com

${ }^{* *}$ In this paper, some results from large researches within the accredited seminar „Улога савремених медија у дигиталном насиљу и физичком здрављу ученика” were presented. This seminar was approved by Zavod za unapređivanje obrazovanja i vaspitanja-Republika Srbija, for 2018/2019, 2019/2020 and 2020/2021seasones, catalogue number 83, Republic of Serbia, https://zuov-katalog.rs/index.php?action=page/catalog/view\&id=1226, authors: Radoje Jevtić \& Jovan Ničković). 


\section{THEORETICAL REVIEW OF THE PROBLEM}

Modern technologies brought a great prosperity in last several years, in every part and sphere of modern life and work. This fast prosperity and transition in, so called "information society", purported new approaches and new demands in many spheres, particularly in the sphere of education. It is obvious fact that pupils and students are already making great use of the benefits of modern technologies. Modern education enables great increasing of knowledge so one very important task of school and teachers is in the accommodation of the education ss content with demands of scientific and technical progress. To realize such a complicated task, teachers must be familiar with modern technologies and use these technologies in everyday life and work. Modern technologies enable design of digital teaching, digital classrooms, virtual laboratories, digital libraries and many other benefits. Knowledge and research are more accessible today than ever. But, use of modern technologies can have and bad consequences, in physical and mental sense. There were many researches, studies, papers etc. that present bad influence of mobile phones, laptops, Internet, Facebook etc. on children and adults (Hardell, 2017; Krasteva, 2018). Because of this reason, the role of teachers gets new and higher dimension. Events in the world and Serbia in the last year related to Covid virus showed that modern technology usage must be intensive, effective and permanent by teachers.

Introduction of a state of emergency in many countries has resulted in online teaching in schools and universities. It is obviously that teachers, pupils and students were forced to use modern technologies for their work and learning even more than they would like, because this was the only way in the arisen situation.Even and before emergency state, there were researches that noted excessive use of modern technologies by pupils, students, even teachers. It is very important that pupils, students and teachers to establish balance in the use of modern technologies. So, it is very important to have an insight in use of modern technologies. There are many modern technologies in use, but for this research, mobile phones, laptops, Internet and social networks, tablets and web applications for online teaching use on teacher`s population before and during Covid virus were presented.

Mobile phones today present one of the most commonly used multimedia devices with huge capabilities. It is almost impossible to imagine real life without mobile phone usage. Related to many researches, the usage of this product of mobile technologies will be greater and greater in future. Usage of modern technologies had a great influence that mobile phone presents not only the phone, but one powerful multimedia device, capable for many different activities and purposes. Today's mobile phones enable high quality of communication, scheduling and holding meetings, online teaching, bills paying, traffic navigation, and many, many other different activities. Related to some realized researches, it is obvious that in the near 
future, mobile phone will present very important device responsible for human`s health and safety. Mobile phones will be capable to communicate with different kinds of sensors arranged on human's body and to measure very important biological parameters, such as, for example pulse and pressure. In case of any disturbance, the relevant institution will be noted via network and proper action will be realized. Also, for example, mobile phones will be capable to communicate with sensors in house, cars and properties, allowing the user to have continuous and real time view of any installed device, what will significantly improve safety in the sense of fire safety, burglary safety and similar.

No matter on its obvious benefits, many scientists and researchers showed bad consequences of excessive use of mobile phones, especially on children population. At the first place, mobile phones present sources of high frequency electromagnetic radiation. Related to many realised researches, increased usage of mobile phones is responsible for many biological, social and emotional problems with their users, such as depression, alienation, uncertainty, insomnias, headaches, neuroses, even and for malignancy problems.

So, it is very important to have a view in mobile phones usage on every population, no matter on their age. Researches in the world (Parasurman, Sam, Yee, Choun, Ren, 2017; Vaidya \& Pathak, 2016) and in Serbia (Jevtić, Ničković, Jevtić, 2011) showed that this medium present one of the most frequently used medium, equally by children and adults.

Because of their performances, laptops today present very commonly used devices in the life and work people with different professions, so as professors, teachers and educators. That enables, at the first place, performancesof their own power supply, easy networking, the ability to store a great amount of data and unlimited mobility. Laptops are constantly getting more powerful, with affordable prices. Researches in the world and in Serbia showed that the usage of this medium constantly increase in last several years.

Laptops present devices that are sources of electromagnetic radiation. The name of laptop purports device that is held on the top of the lap during use. Many researches showed that electromagnetic radiation of laptop can be very dangerous for male population, because of their thermal effects which they may have on male testicles. Male testicles present reproductive organs and their functioning depends from many different biochemical processes. These processes are in the most of cases, temperature dependent. So, even a small temperature change can cause great effects. Very characteristics processes related to male testicles are the process of liquid faction and the process of sperm dilution, which is developing by the influence of prostate enzymes. These processes are temperature dependent. The optimal temperature range for these processes is from $20 \mathrm{C}^{\circ}$ to $37 \mathrm{C}^{\circ}$. For this temperature range, all of enzymes are active. Any temperature change for only of few degrees can cause serious problems. No matter on that very important and disturbing fact, the most of laptop users use their laptops right on their laps. This 
influence could be easy eliminated, placing laptop on the desk or some other pad. Also important fact is that many laptops were connected to networks via routers, by wireless technology. This fact purports that laptop users which use wireless are constantly in the electromagnetic field of routers. This electromagnetic field is not strong, but the increase usage of laptop also increases the presence of and influence of this field.

So, it is also important to have some perception about laptop usage at determinate population, such as population of teachers because this population use laptop for work and other purposes (Jevtić, Ničković, Jevtić, Ničković, 2011; Jevtić \& Jevtić, 2015; Mortazavi, Taeb, Mortazavi, Zarei, Haghani, Habibzadeh, Shojaei-Fard, 2016).

Today, Internet presents very important medium for many different spheres of human life: work, education, market, fun, communication etc. Modern technology enables fast and available Internet for any kind of population, for popular and appropriate prices. Internet can be easily accessed by mobile phone, laptop computer, desktop computer or tablet. In the last time, especially popular Internet usage presents bills paying and other finances online. The usage of Internet for professors, teachers and educators achieved veryimportant meaning in the last year because of Covid virus, when only online teaching was possible. The usage of electronic libraries, electronic books and digital classrooms are only some of Internet advantages.

Social networks also present important part of life for modern population. Researches showed that adults and children visiting social networks and actively participate on them (Jevtić \& Jevtić, 2019; Milovanović, 2019).

Tablet also presents one of the modern devices for Internet and social networks approach, watching clips, browsing the news, photos and many other activities. It can be said that tablet presents solution between laptop and mobile phone. Tablets have screens much bigger then mobile phones what makes them very appropriate for some tasks and activities. It is interesting to note that great number of population thinks that tablet presents device without sense beside mobile phone and laptop. But, there is also determined number of people which thinks that tablet presents great device and use it. One of the most frequently used purposes of tablet is reading of electronic books. Researches showed that the usage of tablets is less than the usage of mobile phones and tablets. Tablets can be very useful in teaching for teachers because they support many applications and they can serve as digital notebooks, but also for many other important and interesting purposes (Major, Hassler, Hennessy, 2017).

There were lot of applications that can be used in teaching, especially in online teaching. The main sense of these applications is to be teaching aids and to increase teaching opportunities. Although there were many divided opinions about their usage and efficiency, the time when the whole world fell into the Covid crisis definitely showed that their usage is very important, so important that these 
applications present the only possibility for online teaching. Researches confirmed that the usage of these applications increased in last past years, especially in the last year and in the current year (Andevski, Vidaković, Arsenijević, 2014).

In this paper, longitudinal researches about use of modern technologies before and during Covid virus on teacher's population were presented. Paper consists of six parts.

The first part of this paper presents theoretical facts and achieved researches. The second part of the paper consists of methodology of researcher. The third part of paper presents realised longitudinal researcher's results. The fourth part of paper presents discussion about realized results and similar realised results. The fifth part presents conclusion and suggestions about future research. The sixth part presents list of used references.

\section{METHODOLOGY}

The main goal of this paper was to present use of modern technologies in the life and work of teachers before and during influence of Corona virus. This main goal was divided into six different tasks of research. The first task was research about mobile phones use. The second task was about laptop use. The third task was about Internet and social network use. The fourth task was about tablets use. The sixth task was about web applications. Every task had different questions as a point of research.

The tasks were presented through three year longitudinal research on teacher's population, in 2018, 2019 and 2020 in Niš, and in seminars realised by author in Serbia.The researches were realised in the form of anonym questionnaire. Covered population consisted of 160 teachers in secondary schools, 30 teachers in elementary schools and 30 teachers from houses of students. The anonym questionnaire was realized through 17 different questions about mobile phones, laptops and desktops computers, tablets, Internet, social networks and learning platforms. It is also important to note that showed researches present a small part of longitudinal researches and measurements related to appliance and usage of modern technologies on school children, students, teachers and people of other different professions (Jevtić, 2020; Jevtić \& Jevtić, 2019; Ranđelović, Veljović, Papić, 2019). 


\section{RESULTS OF RESEARCHES}

\section{Realised results related to mobile phones usage}

This part of research included six questions about mobile phones usage on teachers. The first question was about mobile phones possession by teachers. Results showed, particularly in the last year of research, every teacher possesses mobile phone. The explanation for this is, beside its usefulness, good price and necessity, one more important fact. Many educational institutions insist that every one of their employees must possess mobile phone and provide it for them. It is usually regulated that employees are networked, what purports that communication between them is free. It is important to note that Covid virus hasn't affected on this number.

The results of research about mobile phones possessions by teachers is presented in Table 1.

Table 1. The results of research about mobile phones possessions by teachers

\begin{tabular}{ccc}
\hline Year & Yes & do not possess \\
\hline 2018 & 211 & 9 \\
2019 & 219 & 1 \\
2020 & 220 & 0 \\
\hline
\end{tabular}

The second question was about number of mobile phone numbers by years. It is usual that users of mobile phones most often have two different numbers-one which is private and other which is "official". But, new models of mobile phones have possibilities for installation of more numbers (more cards) so it is not rarity that one user has more than two numbers.

The results of research about mobile phones numbers by teachers showed that teachers mostly use two numbers, what is presented in Table 2.

Table 2. The results of research about the number of mobile phone numbers by years

\begin{tabular}{ccccc}
\hline Year & 1 & 2 & 3 and more & do not possess \\
\hline 2018 & 161 & 46 & 4 & 9 \\
2019 & 130 & 85 & 4 & 1 \\
2020 & 96 & 123 & 1 & 0 \\
\hline
\end{tabular}

The third question was about average duration of one phone call. The results showed an increase in average duration in one phone call by teachers. The biggest number of teachers had duration of one phone call up to 30 minutes during Covid virus. 
Jevtić, R.: The Use of Modern Techologies in the Life and Work of Teachers...

ЗБОРНИК РАДОВА • ГОД. 24 • БР. 23 • ДЕЦЕМБАР 2021 • 151-166

The results of research about average duration of one phone call by teachers are presented in Table 3 .

Table 3. The results of research about the average duration of one phone call

\begin{tabular}{cccccc}
\hline Year & $\begin{array}{c}\text { up to } 10 \\
\text { minutes }\end{array}$ & $\begin{array}{c}\text { up to } \\
\text { 20 minutes }\end{array}$ & $\begin{array}{c}\text { up to 30 } \\
\text { minutes }\end{array}$ & $\begin{array}{c}\text { over 30 } \\
\text { minutes }\end{array}$ & $\begin{array}{c}\text { do not } \\
\text { possess }\end{array}$ \\
\hline 2018 & 72 & 63 & 41 & 35 & 9 \\
2019 & 56 & 74 & 50 & 39 & 1 \\
2020 & 43 & 65 & 67 & 45 & 0 \\
\hline
\end{tabular}

The fourth question was about average duration of all calls in one day. The results showed that before Corona virus, most of the teachers talked up to 60 minutes, in one day. During Corona virus, what was somehow expected, almost all of the teachers talked over 180 minutes in one day.

The results of research about average duration of all phone calls in one day by teachers are presented in Table 4.

Table 4. The results of research about the average duration of all phone calls in one day

\begin{tabular}{cccccc}
\hline Year & $\begin{array}{c}\text { up to 60 } \\
\text { minutes }\end{array}$ & $\begin{array}{c}\text { up to 120 } \\
\text { minutes }\end{array}$ & $\begin{array}{c}\text { up to 180 } \\
\text { minutes }\end{array}$ & $\begin{array}{c}\text { over 180 } \\
\text { minutes }\end{array}$ & $\begin{array}{c}\text { do not } \\
\text { possess }\end{array}$ \\
\hline 2018 & 111 & 66 & 11 & 23 & 9 \\
2019 & 101 & 64 & 27 & 27 & 1 \\
2020 & 0 & 0 & 21 & 199 & 0 \\
\hline
\end{tabular}

The fifth question was about average number of sent messages in one day. The results showed that before Corona virus, most of the teachers sent up to 20 messages and up to 30 messages in one day. During Corona virus, that number rapidly jumped and almost all of teachers sent over 30 messages in one day.

The results of research about the average number of sent messages in one day are presented in Table 5.

Table 5. The results of research about the average number of sent messages in one day

\begin{tabular}{cccccc}
\hline Year & $\begin{array}{c}\text { up to 10 } \\
\text { messages }\end{array}$ & $\begin{array}{c}\text { up to 20 } \\
\text { messages }\end{array}$ & $\begin{array}{c}\text { up to 30 } \\
\text { messages }\end{array}$ & $\begin{array}{c}\text { over 30 } \\
\text { messages }\end{array}$ & $\begin{array}{c}\text { do not } \\
\text { possess }\end{array}$ \\
\hline 2018 & 56 & 78 & 46 & 31 & 9 \\
2019 & 38 & 69 & 70 & 42 & 1 \\
2020 & 0 & 0 & 12 & 208 & 0 \\
\hline
\end{tabular}


The sixth question was about types of mobile phone that teacher use. The results showed that the most common types of mobile phones that teacher use Samsung, Huawei and Xiaomi.

The results of research about type of mobile phone by teachers are presented in Table 6.

Table 6. The results of research about type of mobile phone by teachers

\begin{tabular}{cccccccccc}
\hline Year & Nokia & $\begin{array}{c}\text { Sam- } \\
\text { sung }\end{array}$ & iPho-ne Xia-omi & LG & Asus & Huawei & others & $\begin{array}{c}\text { do not } \\
\text { possess }\end{array}$ \\
\hline 2018 & 5 & 57 & 34 & 36 & 12 & 11 & 49 & 7 & 9 \\
2019 & 4 & 61 & 34 & 39 & 9 & 10 & 56 & 6 & 1 \\
2020 & 4 & 62 & 33 & 41 & 9 & 9 & 53 & 9 & 0 \\
\hline
\end{tabular}

\section{Realised results related to laptop us age}

This part of research included five questions about laptops usage by teachers. The first question was about possession of laptop by teachers. The results showed that almost every teacher has at least one laptop.

The results of research about possession of laptops and number of laptops in possession by teachers are presented in Table 7.

Table 7. The results of research about possession of laptops and number of laptops in possession by teachers

\begin{tabular}{ccccc}
\hline Year & one & two & several & do not possess \\
\hline 2018 & 186 & 24 & 1 & 9 \\
2019 & 190 & 21 & 1 & 8 \\
2020 & 194 & 21 & 1 & 4 \\
\hline
\end{tabular}

The second question was about purpose of laptop usage by teachers. The results showed that most of teachers use laptop for work, Internet, Facebook and similar. The only increase related to time before and during Covid viruss is on the field of education-bigger number of teachers used laptop for education during Covid virus than before.

The results of research about purpose of laptop usage by teachers are presented in Table 8 . 
Jevtić, R.: The Use of Modern Techologies in the Life and Work of Teachers...

ЗБОРНИК РАДОВА • ГОД. 24 • БР. 23 • ДЕЦЕМБАР 2021 • 151-166

Table 8. The results of research about purpose of laptop usage by teachers

\begin{tabular}{cccccccc}
\hline Year & work & education & $\begin{array}{c}\text { Internet, } \\
\text { Facebook } \\
\text { and similar }\end{array}$ & $\begin{array}{c}\text { Video } \\
\text { games }\end{array}$ & Music & Films & $\begin{array}{c}\text { do not } \\
\text { possess }\end{array}$ \\
\hline 2018 & 180 & 95 & 167 & 38 & 43 & 51 & 9 \\
2019 & 184 & 112 & 170 & 39 & 46 & 52 & 8 \\
2020 & 189 & 156 & 176 & 39 & 46 & 55 & 4 \\
\hline
\end{tabular}

The third question was about average laptop usage in one day by teachers. The results showed that usage of laptop rapidly increased during Covid virus, what was expected. The most of teachers use laptop up to 180 minutes and over 180 minutes during Covid virus, while before those numbers were smaller.

The results of research about average laptop usage in one day by teachers are presented in Table 9.

Table 9. The results of research about average laptop usage in one day by teachers

\begin{tabular}{cccccc}
\hline Year & $\begin{array}{c}\text { up to } 60 \\
\text { minutes }\end{array}$ & $\begin{array}{c}\text { up to } 120 \\
\text { minutes }\end{array}$ & $\begin{array}{c}\text { up to } 180 \\
\text { minutes }\end{array}$ & $\begin{array}{c}\text { over } 180 \\
\text { minutes }\end{array}$ & $\begin{array}{c}\text { do not } \\
\text { possess }\end{array}$ \\
\hline 2018 & 43 & 41 & 60 & 67 & 9 \\
2019 & 45 & 44 & 63 & 60 & 8 \\
2020 & 4 & 9 & 71 & 132 & 4 \\
\hline
\end{tabular}

The fourth question was about where is laptop located during usage by teachers. The results showed that almost all teachers use laptop on desk or some other pad but not on lap, what is correct.

The results of research about where is laptop located during usage by teachers are presented in Table 10.

Table 10. The results of research about where is laptop located during usage by teachers

\begin{tabular}{cccc}
\hline Year & lap & $\begin{array}{c}\text { desk or some } \\
\text { other pad }\end{array}$ & do not possess \\
\hline 2018 & 14 & 197 & 9 \\
2019 & 19 & 193 & 8 \\
2020 & 20 & 196 & 4 \\
\hline
\end{tabular}


The fifth question was about laptop's type used by teachers. The results showed that the most common used laptops were Lenovo, Dell and HP. Also, the results showed that the most of teachers possess laptops older than five years. table 11

The results of research about laptop's type used by teachers are presented in

Table 11. The results of research about laptop's type used

by teachers

\begin{tabular}{ccccccccccc}
\hline Year & Dell & Acer & \multicolumn{1}{c}{ Siemens Gigabyte Lenovo } & Asus & Huawei HP & Other $\begin{array}{c}\text { do not } \\
\text { possess }\end{array}$ \\
\hline 2018 & 46 & 13 & 9 & 12 & 52 & 22 & 11 & 41 & 5 & 9 \\
2019 & 47 & 13 & 9 & 12 & 53 & 21 & 11 & 41 & 5 & 8 \\
2020 & 48 & 15 & 9 & 11 & 50 & 21 & 12 & 43 & 7 & 4 \\
\hline
\end{tabular}

\section{Realised results related to Internet and social networks usage}

This part of research included three questions about Internet and social networks usage by teachers. The first question was about average time spent on Internet in one day by teachers. The results showed that more than one half of teachers spent up to 60 minutes before Covid virus, while more than one half of teachers spent up to 120 and up to 180 minutes during Covid virus.

The results of research about average time spent on Internet by teachers are presented in Table 12.

Table 12. The results of research about average time spent on Internet by teachers

\begin{tabular}{cccccc}
\hline Year & $\begin{array}{c}\text { up to 60 } \\
\text { minutes }\end{array}$ & $\begin{array}{c}\text { up to 120 } \\
\text { minutes }\end{array}$ & $\begin{array}{c}\text { up to 180 } \\
\text { minutes }\end{array}$ & $\begin{array}{c}\text { over 180 } \\
\text { minutes }\end{array}$ & $\begin{array}{c}\text { do not } \\
\text { use }\end{array}$ \\
\hline 2018 & 74 & 66 & 40 & 39 & 1 \\
2019 & 63 & 68 & 45 & 44 & 0 \\
2020 & 23 & 72 & 76 & 49 & 0 \\
\hline
\end{tabular}

The second question was about purpose for Internet access by teachers. The only significant increment before and during Covid virus was on field of communication. Slight changes noted on fields of online music, films etc. and social networks.

The results of research about purpose for Internet access by teachers are presented in Table 13. 
Jevtić, R.: The Use of Modern Techologies in the Life and Work of Teachers... ЗБОРНИК РАДОВА • ГОД. 24 • БР. 23 • ДЕЦЕМБАР 2021 • 151-166

Table 13. The results of research about purpose for Internet access by teachers

\begin{tabular}{ccccccccc}
\hline Year & Work & $\begin{array}{c}\text { Online mu- } \\
\text { sic, film... }\end{array}$ & Fun & $\begin{array}{c}\text { Communi- } \\
\text { cation }\end{array}$ & $\begin{array}{c}\text { Video } \\
\text { games }\end{array}$ & $\begin{array}{c}\text { Social } \\
\text { networks }\end{array}$ & Education & $\begin{array}{c}\text { do not } \\
\text { use }\end{array}$ \\
\hline 2018 & 78 & 66 & 59 & 67 & 11 & 168 & 47 & 1 \\
2019 & 77 & 67 & 58 & 74 & 11 & 178 & 45 & 0 \\
2020 & 79 & 56 & 61 & 101 & 10 & 177 & 44 & 0 \\
\hline
\end{tabular}

The third question was about social networks usage by teachers. Related to results, teachers present population very active on social networks. The most common used social networks were Youtube, Facebook, Instagram, Twitter and Linkedin.

The results of research about social networks usage by teachers are presented in Table 14.

Table 14. The results of research about social networks usage by teachers

\begin{tabular}{cccccccccc}
\hline Year & $\begin{array}{c}\text { Face- } \\
\text { book }\end{array}$ & Instagram & $\begin{array}{c}\text { You- } \\
\text { tube }\end{array}$ & $\begin{array}{c}\text { Linke- } \\
\text { din }\end{array}$ & Twitter Pinterest & $\begin{array}{c}\text { Snap- } \\
\text { chat }\end{array}$ & $\begin{array}{c}\text { Tik- } \\
\text { Tok }\end{array}$ & $\begin{array}{c}\text { do not } \\
\text { use }\end{array}$ \\
\hline 2018 & 187 & 111 & 140 & 68 & 111 & 3 & 12 & 0 & 1 \\
2019 & 196 & 139 & 167 & 92 & 119 & 16 & 15 & 1 & 0 \\
2020 & 190 & 152 & 198 & 126 & 137 & 19 & 17 & 4 & 0 \\
\hline
\end{tabular}

\section{Realised results related to Tablets}

This part of research was about tablets usage by teachers. The first question was about tablet possession by teachers. This type of modern technology is not popular in teacher's population, what results showed.

The results of researches about tablet possession are presented in Table 15.

Table 15. The results of research about possession of tablets

\begin{tabular}{ccc}
\hline Year & possess & do not possess \\
\hline 2018 & 27 & 193 \\
2019 & 27 & 193 \\
2020 & 34 & 186 \\
\hline
\end{tabular}


The second question was about tablet's type used by teachers. The results showed that many different types of tablets were equally represented, but, generally, the number of tablets was too small for valid evaluation. table 16

The results of research about tablet's type used by teachers are presented in

Table 16. The results of research about tablet's type used by teachers

\begin{tabular}{ccccccccccc}
\hline Year & $\begin{array}{c}\text { Hua- } \\
\text { wei }\end{array}$ & Alcatel & Apple & Samsung Lenovo & HP & Acer & Toshiba other & $\begin{array}{c}\text { do not } \\
\text { use }\end{array}$ \\
\hline 2018 & 2 & 2 & 1 & 6 & 3 & 3 & 4 & 4 & 2 & 193 \\
2019 & 2 & 2 & 1 & 7 & 3 & 3 & 4 & 4 & 2 & 193 \\
2020 & 3 & 3 & 1 & 9 & 6 & 4 & 4 & 2 & 2 & 186 \\
\hline
\end{tabular}

\section{Realised results related to web application that can be used in online teaching}

This part of research included one question about usage of web applications in teaching. For several years ago, teachers use many different applications that can improve the teaching of material and pupils knowledge. Also, many different administrative tasks can be easily realised. The results showed that before Covid virus, the most common used applications were Moodle, Viber and Prezi. During Covid virus, the most common applications were Viber, MS Teams, Moodle and Discord.

The results of researches are presented in Table 17.

Table 17. The results of research about web application usage

\begin{tabular}{cccccccccc}
\hline Year & Google & Prezi & Skype & Viber & $\begin{array}{c}\text { MS } \\
\text { Teams }\end{array}$ & Discord & Moodle & other $\begin{array}{c}\text { do not } \\
\text { use }\end{array}$ \\
\hline 2018 & 67 & 89 & 35 & 79 & 0 & 57 & 119 & 4 & 9 \\
2019 & 65 & 87 & 41 & 95 & 0 & 62 & 129 & 2 & 8 \\
2020 & 58 & 62 & 59 & 167 & 163 & 143 & 149 & 2 & 3 \\
\hline
\end{tabular}




\section{DISCUSSION}

Realized research results showed that usage of modern technologies present very important part in teachers. Although there is a fact that children and younger generations significantly faster adopt modern technologies, teachers are following them constantly. Several years before, population that didn't have adequate "technical education" had great problems with modern technologies usage. Today, thanks to the modern way of approach and education, modern technologies are adopted by many different populations. Although the time during Corona virus, on some way, forced many teachers to use laptops, desktops, mobile phones, tablets, Internet, learning platforms and other much more frequently and much more, the realized effects were good. Online teaching, although it was the only way of teaching during Corona virus, showed many benefits.

Related to realized research presented in this paper, the number of mobile phones and mobile phones usage increased in past three years. They were used for many different reasons and purposes because they are practical and economically available. Results showed that every of teachers had at least one mobile phone in 2020. Covid virus affected that teachers were talking much more during virus and sent much more messages during virus then before. The most used mobile phone type was Samsung.

Related to laptops, realized research showed increase laptop usage in past three years. Covid virus affected that teachers were using laptop more than 180 minutes during virus than before. The most common purpose for using a laptop is work. Also, realized results showed that very big number of teachers own laptops. The most teachers use a laptop on a pad. The most used laptop type was Lenovo.

Related to Internet, realised results showed increased usage of Internet. The most common purpose of Internet usage is approach to social networks. The most common used social networks are Facebook and Youtube.

Related to tablets, realized results showed that small number of teachers owntablets. The most probable reason for "unpopularity" of tablets on teacher's population is in the fact that there are many powerful mobile phones and laptops on the market that completely satisfy all needs so that possession of tablet would probably unnecessary surplus. The number of teachers that use tablets was too small to evaluate which type of tablet was the most used.

Related to web applications that can be used in online teaching, realized results showed that the usage of these applications increased in the past of three years, especially during Covid virus. The most used web applications for online teaching are Viber, MS Teams and Moodle. It is important to note that MS Teams application started to use in 2020, while other applications were used earlier. It can be also concluded that big number of teacher possess good digital literacy. 


\section{CONCLUSION AND FUTURE INVESTIGATION}

The usage of modern technologies enables great benefits in teaching and educational work. Teachers do use modern technologies and they are very good familiar with it. It is very important, for two reasons. The one is related on better efficiency of teaching and educational work. The other is in the possibility of recognizing the impact of the bad effects of modern technologies on children and students. For example, one of those effects is digital violence. Digital violence presents very complex term and appearance and must be treated very detail and seriously. Teachers beside parents have a very important role in these problems.

Realised results show the insight in the use of modern technologies on teacher's population, before Covid virus and during Covid virus. Although usage of modern technologies has great benefits, there are also bad effects and consequences that must be predicted and stopped, especially on populations of children, pupils and students. Future investigations should lead in several directions. One direction should be in measuring of electromagnetic radiation of different devices (mobile phones, laptops, tablets etc.) and control of exposition to these devices. Other direction should be in permanent researches of digital violence between children, pupils and students and realise tasks (tribunes, lecturers, presentations, propositions for changes in law, educations of parents in right approach and similar) in order to prevent, predict and stop digital violence.

\section{References}

Andevski, M., Vidaković, M. i Arsenijević, O. (2014). Internet u nastavi i učenju. Sinteza, 368-374. DOI 10.15308/SInteZa-2014-368-374.

Hardell, L. (2017). Effects of Mobile Phones on Children's and Adolescents' Health: A Commentary. Child Development, Vol. 00, 1-4.

Jevtić, B. R. i Jevtić, D. D. (2015). Uticaj modernih tehnologija na život i rad školske dece. Učenje i nastava, 2, 383-398.

Jevtić, B. R., Ničković, T. J., Jevtić, D. D. \& Ničković, S. V. (2011). Electromagnetic field and heating measuring results of lap tops. Facta universitatis, Working and Environmental Protection, 8(1), 13-19.

Jevtić, B. R., Ničković, T. J. i Jevtić, D. D. (2011). SAR i termički efekti mobilnih telefona. Tehnika elektrotehnika, 1, 95-99.

Jevtić, B. R. (2020). Digital Violence and the Role of Different Factors in Its Prevention and Sanction in Serbia. Zbornik radova Pedagoškog fakulteta u Užicu, 23(22), 195-212. DOI 10.5937/ZRPFU2022195J. 
Jevtić, R. \& Jevtić, D. (2019). The Internet Addiction As A Problem. In School Age Children. Zdravstvena zaštita, 48(3), 49-55.

Krasteva, N. (2018). Existing Dangers for the Child on the Internet. International conference Knowledge-Based Organization, 24(2), 206-211. DOI 10.1515/kbo2018-0091.

Major, L., Hassler, B. \& Hennessy, S. (2017). Tablet Use in Schools: Impact, Affordances and Considerations. In A. Marcus-Quinn \& T. Hourigan (eds.), Handbook for Digital Learning in K-12 Schools, 115-128. DOI 10.1007/978-3319-33808-8_8.

Microsoft Teams for Education (2021). Najbolje prakse za školske lidere koji kreiraju timove i kanale u Microsoft timovima za obrazovanje. Retrieved March 01, 2021. from the World Wide Web https://support.microsoft.com/sr-latn-rs/topic/najboljeprakse-za-\%C5\%A1 kolske-lidere-koji-kreiraju-timove-i-kanale-u-microsofttimovima-za-obrazovanje-f3663ad9-a835-4971-9acb-6725a543c003.

Milovanović, S. (2019). Nasilje na Internetu - kriminološki aspekt. Unpublished master theisis. Univerzitet u Nišu: Pravni fakultet.

Mortazavi, S., Taeb, S., Mortazavi, S. T. M. J., Zarei, S., Haghani, M., Habibzadeh, P. \& Shojaei-Fard, M. B. (2016). The Fundamental Reasons Why Laptop Computers should not be Used on Your Lap. Journal of Biomedical Physics \& Engineering, 6(4), 279-284.

Parasurman, S., Sam, A. T., Yee, S. W. K., Choun, B. L. C. \& Ren, L. Y. (2017). Smartphone usage and increased risk of mobile phone addiction: A concurrent study. International Journal of Pharmaceutical Investigation, 7(3), 125-131.

Ranđelović, M., Jevtić, R., Veljović, A. i Papić, M. (2019). IKT u nastavi kroz digitalni dijalog - pametno i bezbedno. In A. Veljović (ed.), Nacionalna konferencija sa međunarodnim učešćem Informacione tehnologije, obrazovanje i preduzetništvo ITOP 19, 6-7. 4. 2019., Čačak (1-12). Čačak: Tehnički fakultet.

Vaidya, A. \& Pathak, V. (2016). Mobile Phone Usage among Youth. International Journal of Applied Research and Studies, 5(3), 1-16. 


\section{Радоје Б. Јевтић}

Електротехничка школа „Никола Тесла”, Ниш

\section{КОРИШЋЕЊЕ САВРЕМЕНИХ ТЕХНОЛОГИЈА У ЖИВОТУ И РАДУ НАСТАВНИКА ПРЕ И ТОКОМ КОВИД ВИРУСА}

\section{Резиме}

Савремене технологије представљају готово сваки део људског живота и рада. Једна од најважнијих сфера у животу човека је образовање. Продор савремених технологија у ову животну сферу је огроман, посебно у неколико протеклих година. Ове чињенице подразумевају да наставници, професори и други едукатори морају упознати и учити своје ђаке да поменуте технологије користе на одговарајући начин. Њихова улога је веома важна и комплексна. Наставници морају наћи одговарајући начин да реализују равнотежу између „дигиталних” вештина потребних ђацима да прихвате школски материјал, користе бенефите „дигиталног” окружења и наставе да користе и развијају машту и друге активности старијих „недигиталних" генерација. Наставници морају да константно уче и буду упознати са савременим технологијама и њиховим бенефитима и користе их у животу и раду. Савремене технологије су различите, али у основним школама, средњим школама и домовима ученика, најчешће су коришћени мобилни телефони, лаптопови, таблети, интернет, социјалне мреже итд. Главни циљ овог рада јесте да представи резултате употребе савремених технологија у животу и раду наставника. Истраживања представљена у раду, реализована од стране аутора, представљена су као лонгитудинална истраживања и укључују наставника у различитим просветним институцијама, као што су основне школе, средње школе и домови ученика.

Кључне речи: савремене технологије, школа, наставници, ковид-19. 